\title{
Empowering Leadership and Individual Creativity: The Moderation Role of Individual Competence Facing Covid-19 Pandemic
}

\author{
Yuni Siswanti' ${ }^{1}$ Joko Susanto ${ }^{1}$ \\ 1Universitas Pembangunan Nasional "Veteran" Yogyakarta, Indonesia
}

\begin{abstract}
Background - The COVID-19 pandemic impacts public health and the Indonesian people's economic conditions, education, and social life. Vocational high school graduates who have been looking for work in the last two years have experienced significant disruption due to the Covid-19 pandemic. Competition in the labor market is very high and coincides with the worker who has also experienced termination of employment (PHK) from the company.
\end{abstract}

Research Purpose - This study tests and analyzes the influence of empowering leadership on individual creativity, moderated by competence.

Research Methodology - Research conducted survey method on vocational high school graduate or equivalent in the Yogyakarta Special Region (Sleman Regency, Yogyakarta Municipality, Bantul, Kulonprogo, and Gunungkidul). Sampling was done by convenience sampling and data collection by distributing questionnaires (google form). The number of respondents who filled out and returned the questionnaire was 108 people. The data analysis technique used in SPSS 24. Test the instrument with a test of validity (Confirmatory Factor Analysis) and reliability by looking at Cronbach Alpha. Hypothesis testing using simple regression (H1 test) and tiered regression test (H2 test).

Research Result / Contribution - The results of this study found that: there are several limitations in this research that require further research. (1) there is an influence of empowering leadership on individual creativity, (2) this influence is moderated by competence. This research has practical implications for leaders, and the discussion results show that further research still needs to be discussed.

Keywords: empowering leadership, individual creativity, competence

This is an open access article under the CC-BY-NC license

\section{INTRODUCTION}

The impact of the COVID-19 pandemic will impact public health and the economic conditions, education, and social life of the Indonesian people. This pandemic has caused several regional governments to enforce Large-Scale Social Restrictions (PSBB) policies which have implications for limiting community activities, including economic activities, educational activities, and other social activities. This condition is also experienced by alumni of vocational high schools throughout Indonesia. Vocational high school graduates who have been looking for work in the last two years have experienced significant disruption due to the Covid-19 pandemic. Meanwhile, vocational high school alumni who graduated this year experienced teaching difficulties in the latter part of their studies. The immediate impact they experience is a major distraction in the final judgment they should receive. However, under any conditions, they still pass in this heartbreaking global recession. The labor market conditions that tend to be problematic are a new obstacle for graduates. Competition in the labor market is very high and 
coincides with the worker who has also experienced termination of employment (PHK) from the company. (Bobonis \& Morrow, 2014).

Companies must continue to push their staff to be innovative (Siswanti \& Muafi, 2020); (Shalley \& Gilson, 2004). Creativity refers to a unique and new product, which is helpful from a person or by a group of individuals (Madjar et al., 2002); (Shalley et al., 2000); (Shalley \& Zhou, 2004). Leaders need to support individuals so that creativity occurs in organizations (Shalley \& Gilson, 2004).

Some research has looked into the effect of leadership on creativity. Nonetheless, the majority of this research (Amabile et al., 2004) has focused on organizational support and member-leader exchange (Tierney et al., 1999). According to research by Siswanti and Muafi (2020 individual creativity is boosted when leaders are empowered. Previous research (Mumford et al., 2002); (Tierney, 2008) has also been conducted in order to focus more efforts on leadership empowerment approaches in order to maximize employee creativity. Little study has been done on the impact of leadership empowerment on individual creativity. (particularly among vocational high school graduates). As a result, the main goal of this research was to look into the impact of leadership empowerment on the creativity of Yogyakarta Special Region vocational high school graduates.

Empowering leadership is defined as a condition in which a leader gives followers more power, autonomy, incentive, and other job benefits. Furthermore, empowering leaders will aid individual change readiness, but past research has yielded conflicting findings. Empowering leaders, for example, support personal willingness to transform (Holten \& Brenner, 2015); (Muafi et al., 2019); (Lee et al., 2019); (Holten \& Brenner, 2015); (Holten \& Brenner, 2015); (Holten \& Brenner, 2015); (Holten \& Brenner, 2015); (Holten \& Brenner, 2015); (Holten (Dong et al., 2017). According to (Stewart et al., 2010), (Meng et al., 2016); (Lee et al., 2017); (Amundsen et al., 2014); (Lee et al., 2018), empowering leaders is insufficient to raise individual readiness for change.

Mechanisms are required to be the primary driver of personal preparedness change. It is shaped by the outcomes or repercussions of empowered leadership's execution. The findings of the study (Fong \& Snape, 2015) suggest that empowering leaders has a direct impact on staffs' willingness to participate in the creative process because leaders tend to build followers' confidence and emphasize the value of leadership, work procedures, and work independently. As a result, a person can become more invested in his job and participate in a process that produces innovative results. Furthermore, empowering leaders will boost psychological empowerment, particularly among those who wish to be empowered. When staff's empowering role identity is high, enabling leaders to have a beneficial impact on their psychological strength. When psychological empowerment is high, it has an impact on the creative process' involvement.

\section{LITERATURE REVIEW}

\section{Empowering Leadership and Individual Creativity}

Empowering leadership is defined as a circumstance in which a leader contributes to followers' authority, autonomy, motivation, and other advantages (Siswanti \& Muafi, 2020; Zhang \& Bartol, 2010; Sims et al., 2009; Muafi et al., 2019). The features of empowering leadership behavior, according to Martin et al. (2013), facilitate members' autonomy and competence. Aburuman Research (2016); Zhang \& Bartol (2010); Zhang \& Zhou (2014); Ekmecelioglu \& Zbag (2014) found that empowering leadership is an important factor on staff creativity. The findings of Fong and Snape's (2015) study show that empowering leaders has an impact on staffs' willingness to participate in the creative process because leaders tend to build followers' confidence, emphasize the essence of leadership and duty processes, and give them the 
freedom to do their jobs. As a result, staff can get more invested in his task, which can lead to more innovative results.

H1: Empowering leadership has a positive effect on individual creativity

\section{Empowering Leadership-Individual Competence-Creativity}

Wibowo et al. (2007) define competence as the ability to complete a job or task based on skills, knowledge and the work attitude required by the job. Competence, according to Veithzal (2003), is a skill, skill, and ability. Competent is the root term, which implies "capable, capable, skilled." Competence refers to a person's qualities or characteristics that enable him to be effective at his job.

Research by Fong \& Snape (2015), Duan., Tang., Li, Y., Cheng., \& Zhang (2020) show that organizational support in leaders who can empower members will affect individual creativity. The research recommendation of Duan et al. (2020) states that many factors may influence the strong impact of leadership empowerment on individual creativity. One of them is personal competence. Therefore, this study wants to examine the role of competence in moderating the impact of leader empowerment on individual creativity.

H2: Empowering leadership affects individual creativity moderated by competence

\section{RESEARCH METHOD}

This research method uses a survey by distributing questionnaires to alumni of vocational high school or equivalent in Yogyakarta Special Region covering Sleman, Bantul, Kunlonprogo, Gunungkidul, and Yogyakarta Municipality.

\section{Population}

The population in this study is the alumni of vocational high school or equivalent in Yogyakarta Special Region who are currently working, totaling 108 people.

\section{Measurement}

Instrument measures empowering leadership using the ELQ instrument (Arnold et al., 2000), 38 items. Individual creativity was measured by 13 items adopted from the creativity measure of Tierney et al. (1999). Personal competence adopted the 20 items Spencer \& Spencer instrument (1993). All instruments were measured using a 7 -point Likert scale (1=strongly disagree to $6=$ strongly agree).

\section{Instrument Testing}

The instrument test was carried out by testing the validity using confirmatory factor analysis and reliability testing. Cronbach Alpha showed the results of the reliability test. According to Hair et al. (2019), the limit of the reliability test is 0.7 , whereas if $=0.6$, it can be accepted in exploratory research.

\section{Hypothesis testing method}

Hypothesis test (H1) using simple regression. The $\mathrm{H} 2$ test uses a tiered regression. 
RSF Conference Series: Business, Management and Social Sciences, Vol. 1 (3), 375-383 Empowering Leadership and Individual Creativity: The Moderation Role of Individual Competence Facing Covid19 Pandemic

Yuni Siswanti, Joko Susanto

\section{FINDINGS AND DISCUSSION}

\section{Respondent Profile}

Table 1. Profile of Respondent

\begin{tabular}{|c|c|c|c|}
\hline Profile & Description & $\begin{array}{c}\text { Amount } \\
\text { (person) }\end{array}$ & $\begin{array}{c}\text { Percentage } \\
\text { (\%) }\end{array}$ \\
\hline \multirow{2}{*}{ Age (years) } & $20-25$ & 70 & 64.82 \\
\cline { 2 - 4 } & $26-30$ & 20 & 18.51 \\
\cline { 2 - 4 } & $>30$ & 18 & 16.67 \\
\hline \multirow{2}{*}{ Gender } & Men & 45 & 41.67 \\
\cline { 2 - 4 } & Women & 63 & 58.33 \\
\hline Experience (years) & $<1$ & 10 & 9.26 \\
\hline & $1-3$ & 48 & 44.44 \\
\hline & $4-6$ & 35 & 32.41 \\
\hline & $>6$ & 15 & 13.89 \\
\hline Married Status & Unmarried & 77 & 71.29 \\
\hline & Married & 31 & 28.71 \\
\hline & Jumlah & 108 & 100.0 \\
\hline
\end{tabular}

Source: Primary data

Table 1 exhibits that the larger part of respondents from vocational high school alumni aged between 20 to 25 years is $64.82 \%$. Women dominated respondents by $58.3 \%$. The longest working period of $1-3$ years is $44 \%$, and most respondents are unmarried (71.29\%).

\section{Validity and Reliability Test Results}

The results of the CFA test, all instruments for the three variables were declared valid because their values were above 0.6 (loading factor $>=0.6$ ). Therefore, and each item was grouped according to its variables. The reliability test results showed that the three research variables were reliable because Cronbach's Alpha coefficients $>0.6$.

Descriptive Test Results

Table 2. Descriptive Statistics

\begin{tabular}{cc|r|r|c|c} 
& $\mathrm{N}$ & Minimum & Maximum & Mean & Std. Deviation \\
\hline Leadership Empowerment (X) & 108 & 2.87 & 4.37 & 4.43 & .6441 \\
\hline Kompetence (Z) & 108 & 2.85 & 4.49 & 4.57 & .5731 \\
\hline Individual Creativity (Y) & 108 & 3.00 & 6.12 & 4.67 & .7237 \\
\hline Valid N (listwise) & 108 & & & & \\
\hline
\end{tabular}

Source: Primary data processing

Meanwhile, Table 2 shows that the descriptive average of the variables is high because it has an average value above 4.00. In general, it can be said that vocational high school alumni in Yogyakarta have a high perception of the empowering leadership they have experienced so far, high individual competence, and creativity. 
RSF Conference Series: Business, Management and Social Sciences, Vol. 1 (3), 375-383

Empowering Leadership and Individual Creativity: The Moderation Role of Individual Competence Facing Covid19 Pandemic

Yuni Siswanti, Joko Susanto

\section{Hypothesis Test Results}

Table 3. The Effect of Leadership Empowerment on Psychological Empowerment Coefficients

\begin{tabular}{|c|c|c|c|c|c|c|}
\hline \multirow[b]{2}{*}{ Model } & & \multicolumn{2}{|c|}{$\begin{array}{l}\text { Unstandardized } \\
\text { Coefficients }\end{array}$} & \multirow{2}{*}{$\begin{array}{c}\text { Standardized } \\
\text { Coefficients } \\
\text { Beta }\end{array}$} & \multirow[t]{2}{*}{$\mathrm{t}$} & \multirow[t]{2}{*}{ Sig. } \\
\hline & & $\mathrm{B}$ & Std. Error & & & \\
\hline \multirow[t]{2}{*}{1} & (Constant) & 2.439 & .258 & & 4.734 & .000 \\
\hline & $\begin{array}{c}\text { Leadership } \\
\text { Empowerment } \\
(\mathrm{X})\end{array}$ & .536 & .059 & .643 & 8.233 & .020 \\
\hline
\end{tabular}

a.Dependent Variable: Individual Creativity (Z)

The leadership empowerment variable has a significant value of $0.000<0.05$, as shown in Table 3 (test stage 2). It suggests that empowering leaders has a positive and large impact on the creativity of working vocational high school graduates, indicating that $\mathrm{H} 1$ is supported.

Table 4. Moderation Regression Test

\begin{tabular}{|cll|rrrrrrr|}
\hline & & & R Square & B & S.E & t & P & Hypotheses \\
\hline LE $\rightarrow$ & IC & & .037 & .643 & .059 & 8.233 & .020 & H1: supported \\
& & & & & & & & \\
\hline LE, C, Interaction & $\rightarrow$ & IC & .058 & .702 & 4.276 & 7.276 & .000 & H2: supported \\
\hline
\end{tabular}

Source: Primary data processing

In the stepwise regression test, it is known that the $\mathrm{R}$ Square value of the second stage of the regression test is 0.058 , and the $\mathrm{R}$ Square of the stage 1 regression is 0.37 . There is an increase in the influence of leadership empowerment on individual creativity when there is personal competence. Thus $\mathrm{H} 2$ is supported, meaning that competence plays a role in moderating the impact of leadership empowerment on individual creativity.

\section{Discussion}

The hypothesis 1 test, which claims that empowered leadership has a beneficial impact on individual creativity, was found to be true. The results of this research support the research of Conger \& Kanungo (1988); Frank, \& Liu (2018); Aburaman (2016); Zhang \& Bartol (2010); Zhang \& Zhou (2014); Fong \& Snape (2015); Duan., Tang., Li, Y., Cheng., \& Zhang (2020); Malik (2021). Çekmecelioğlu \& Zbağ (2014) Ekmeceliolu \& Zba (2014) studied the influence of psychological empowerment on individual creativity, focusing on four cognitions (competence, influence, self-determination, and meaningfulness). According to their findings, psychological empowerment has a significant impact on individual creativity. Employees will be more imaginative and work harder if they find their employment worthwhile. Unique creativity has a good association with competence and effects. In the face of the present COVID-19 pandemic, vocational high school alumni in Yogyakarta Special Region are also experiencing it. They endeavor to make their work more meaningful, which is accompanied by a rise in self-competence and self-determination awareness, both of which have an impact on employees' high creativity. 
Hypothesis 2, which states that leadership empowerment positively affects individual creativity, moderated by competence, is supported. This research succeeded in answering the research recommendations of Duan et al. (2020), which stated that many factors probably influenced the strong influence of leadership empowerment on individual creativity. One of them is personal competence. Vocational high school graduates who work in MSMEs and companies/industries who feel high leadership empowerment will continually improve their creativity. They make this effort to produce a good performance and be maintained as employees during the current pandemic. When vocational high school graduates already have adequate competence to meet the organization's needs, the impact of leadership empowerment on developing individual creativity is much stronger. The competencies possessed are manifested in broader skills in carrying out work, sufficient knowledge and understanding of their work, high work values, interests, and professional work attitudes.

\section{CONCLUSION AND FUTURE RESEARCH \\ Conclusion}

Empowering leadership positively affects individual creativity, and personal competence moderates the influence of empowering leadership on individual creativity.

\section{Research Contribution}

The managerial contributions of this research are: leaders/managers can try to increase employees' creativity by empowering them to do their tasks. Individual creativity can be developed when the leader gives each employee/personal freedom to express their ideas. On the other hand, personal competencies can be pursued by leaders/managers through various ways such as: providing training opportunities, continuing studies to a higher level for individuals who are considered to have high intellectual intelligence and good school interests, bringing in instructors or experts to provide appropriate training with today's needs, as well as sending employees to other organizations to learn so that their competence is increased. When competence rises, it will increase the relationship of leadership empowerment to individual creativity. Individual creativity can affect personal achievement so that it has a beneficial effect on the company.

\section{Research limitations and recommendations}

This study only took respondents from vocational school graduates or graduates from peer schools. The population is still quite small. More research should be done on alumni with higher education levels, such as a diploma or university alumni, who have a large number of respondents and live outside of Yogyakarta Special Region.

This study only includes individual competence as a moderating variable. Further research should develop other moderating variables that might influence the relationship of leadership empowerment to individual creativity, such as personality, self-efficacy, locus of control, organizational commitment, job satisfaction, organizational culture, employee engagement, and personal characteristics.

\section{ACKNOWLEDGEMENT}

The authors would like to thank the Institute for Research and Community Service at Universitas Pembangunan Nasional Veteran Yogyakarta, Indonesia, for providing funds for this research 


\section{REFERENCES}

Aburuman, N. M. (2016). The impact of administrative empowerment on creativity improvement among the workers of Jordanian public administration institute. International Journal of Business and Social Science, 7(1), 182-190.

Ahearne, M., Mathieu, J., \& Rapp, A. (2005). To empower or not to empower your sales force? An empirical examination of the influence of leadership empowerment behavior on customer satisfaction and performance. Journal of Applied psychology, 90(5), 945-960.

Ahmad, A., Ibrahim, R., \& Bakar, A. (2018). Factors influencing job performance among police personnel: An empirical study in Selangor. Management Science Letters, 8(9), 939-950.

Amabile, T. M. (1988). A model of creativity and innovation in organizations. Research in organizational behavior, 10(1), 123-167.

Amabile, T. M., Conti, R., Coon, H., Lazenby, J., \& Herron, M. (1996). Assessing the work environment for creativity. Academy of management journal, 39(5), 1154-1184.

Amabile, T. M., Schatzel, E. A., Moneta, G. B., \& Kramer, S. J. (2004). Leader behaviors and the work environment for creativity: Perceived leader support. The Leadership Quarterly, 15(1), 5-32.

Amundsen, S., \& Martinsen, Ø. L. (2014). Empowering leadership: Construct clarification, conceptualization, and validation of a new scale. The leadership quarterly, 25(3), 487-511. Arnold, J. A.,

Arad, S., Rhoades, J. A., \& Drasgow, F. (2000). The empowering leadership questionnaire: The construction and validation of a new scale for measuring leader behaviors. Journal of organizational behavior, 21(3), 249-269.

Baron, R. M., \& Kenny, D. A. (1986). The moderator-mediator variable distinction in social psychological research: Conceptual, strategic, and statistical considerations. Journal of Personality and Social Psychology, 51, 1173-1182.

Bobonis, G. J., \& Morrow, P. M. (2014). Labor coercion and the accumulation of human capital. Journal of Development Economics, 108, 32-53.

Çekmecelioglu, H., \& \& Özbag, G. K. (2014). Linking psychological empowerment, individual creativity and firm innovativeness: A research on Turkish manufacturing industry. Business Management Dynamics, 3(10), 1-17.

De Klerk, S. \& Stander, M. W. (2014). Leadership empowerment behaviour, work engagement and turnover intention: The role of psychological empowerment. Journal of Positive Management, 5(3), 28- 45.

Conger, J. A., \& Kanungo, R. N. (1988). The empowerment process: Integrating theory and practice. Academy of management review, 13(3), 471-482.

Dong, Y., Bartol, K. M., Zhang, Z.X., \& Li, C. (2017). Enhancing employee creativity via individual skill development and team knowledge sharing: Influences of dual-focused transformational leadership. Journal of Organizational Behavior, 38(3), 439-458.

Duan, W., Tang, X., Li, Y., Cheng, X., \& Zhang, H. (2020). Perceived organizational support and employee creativity: The mediation role of calling. Creativity Research Journal, 32(4), 403-411.

Fong, K. H. \& Snape, E. (2015). Empowering leadership, psychological empowerment and employee outcomes: Testing a multi-level mediating model. British Journal of Management, 26, 126-138.

Gilson, L. L., \& Shalley, C. E. (2004). A little creativity goes a long way: An examination of teams' engagement in creative processes. Journal of management, 30(4), 453-470.

Hair, J. F., Page, M., \& Brunsveld, N. (2019). Essentials of business research methods. Routledge.

Holten, A. L., \& Brenner, S. O. (2015). Leadership style and the process of organizational change. Leadership and Organization Development Journal. https://doi.org/10.1108/LODJ-11- 2012-0155 
Kirkman, B. L., \& Rosen, B. (1999). Beyond self-management: Antecedents and consequences of team empowerment. Academy of Management Journal. https://doi.org/10.2307/256874 Lee, A., Willis, S., \& Tian, A. W. (2018). Empowering leadership: A meta-analytic examination

of incremental contribution, mediation, and moderation. Journal of Organizational Behavior, 39(3), 306-325.

Lee, Y. H., Lu, T. E., Yang, C. C., \& Chang, G. (2019). A multilevel approach on empowering leadership and safety behavior in the medical industry: The mediating effects of knowledge sharing and safety climate. Safety Science, 117, 1-9.

Lee, M. C. C., \& Ding, A. Y. L. (2020). Comparing empowering, transformational, and transactional leadership on supervisory coaching and job performance: A multilevel perspective. PsyCh Journal. https://doi.org/10.1002/pchj.345

Lee, Y. S., Chang, J. Y., \& Choi, J. N. (2017). Why reject creative ideas? Fear as a driver of implicit bias against creativity. Creativity Research Journal, 29(3), 225-235.

Madjar, N., Oldham, G. R., \& Pratt, M. G. (2002). There's no place like home? The contributions of work and nonwork creativity support to employees' creative performance. Academy of Management journal, 45(4), 757-767.

Malik, S. (2021). Impact of Empowering Leadership on Employee Creativity in Projects with Mediating Effect of Creative Self-Efficacy and Moderation of Project Culture (Doctoral dissertation, CAPITAL UNIVERSITY).

Martin, S. L., Liao, H., \& Campbell, E. M. (2013). Directive versus empowering leadership: A field experiment comparing impacts on task proficiency and proactivity. Academy of Management Journal, 56(5), 1372-1395.

Meng, L., Jin, Y., \& Guo, J. (2016). Mediating and/or moderating roles of psychological empowerment. Applied Nursing Research, 30, 104-110.

Muafi, Fachrunnisa, O., Siswanti, Y., El Qadri, Z. M., \& Harjito, D. A. (2019). Empowering Leadership and Individual Readiness to Change: the Role of People Dimension and Work Method. Journal of the Knowledge Economy, 10(4), 1515-1535.

Mumford, M. D., Scott, G. M., Gaddis, B., \& Strange, J. M. (2002). Leading creative people: Orchestrating expertise and relationships. The leadership quarterly, 13(6), 705-750.

Namasivayam, K., Guchait, P., \& Lei, P. (2014). The influence of leader empowering behaviors and employee psychological empowerment on customer satisfaction. International Journal of Contemporary Hospitality Management, 26(1), 69-84.

Özarallı, N. (2015). Linking empowering leader to creativity: The moderating role of psychological (felt) empowerment. Procedia - Social and Behavioral Sciences, 181, 366- 376.

Raub, S. \& Rober, C. (2010). Differential effects of empowering leadership on in-role and extra- role employee behaviors: Exploring the role of psychological empowerment and power values. Human Relations, 63(11), 1743-1770.

Shalley, C. E., \& Gilson, L. L. (2004). What leaders need to know: A review of social and contextual factors that can foster or hinder creativity. The leadership quarterly, 15(1), 33- 53.

Shalley, C. E., Gilson, L. L., \& Blum, T. C. (2000). Matching creativity requirements and the work environment: Effects on satisfaction and intentions to leave. Academy of management journal, 43(2), 215223.

Shalley, C. E., Zhou, J., \& Oldham, G. R. (2004). The effects of personal and contextual characteristics on creativity: Where should we go from here?. Journal of management, 30(6), 933-958. 
Sims Jr, H. P., Faraj, S., \& Yun, S. (2009). When should a leader be directive or empowering? How to develop your own situational theory of leadership. Business Horizons, 52(2), 149- 158.

Siswanti, Y., \& Muafi, M. (2020). Empowering leadership and individual creativity: The mediation role of psychological empowerment in facing covid-19 pandemic. The Journal of Asian Finance, Economics, and Business, 7(11), 809-816.

Spencer, L. M.\& Spencer. (1993). Competence at work.

Stewart, J. G., McNulty, R., Griffin, M. T. Q., \& Fitzpatrick, J. J. (2010). Psychological empowerment and structural empowerment among nurse practitioners. Journal of the American Academy of Nurse Practitioners, 22(1), 27-34.

Thomas, K. W., \& Velthouse, B. A. (1990). Cognitive elements of empowerment: An "interpretive" model of intrinsic task motivation. Academy of management review, 15(4), 666-681.

Veithzal. 2003. Kepemimpinan dan Perilaku Organisasi. Jakarta: PT Raja Grafindo Persada. Wibowo, S. E., \& Phil, M. (2007). Manajemen Kinerja. Jakarta: PT Rajagrafindo Persada.

Tierney, P., Farmer, S. M., \& Graen, G. B. (1999). An examination of leadership and employee creativity: The relevance of traits and relationships. Personnel psychology, 52(3), 591-620. Veithzal Rivai. 2014. Manajemen Sumber Daya Manusia untuk Perusahaan, Edisi ke 6, PT. Raja

Grafindo Persada, Depok, 16956.

Wang, H., Demerouti, E., \& Le Blanc, P. (2017). A job crafting perspective on empowering leadership and job performance. In Academy of Management Proceedings (Vol. 2017, No. 1, p. 13785). Briarcliff Manor, NY 10510: Academy of Management.

Wibowo. ( 2007). Manajemen Kinerja. Edisi ketiga.Jakarta: PT.Raja Grafindo Prasada.

Zhang, S., Ke, X., Frank Wang, X. H., \& Liu, J. (2018). Empowering leadership and employee creativity: a dual-mechanism perspective. Journal of Occupational and Organizational Psychology, 91(4), 896-917.

Zhang, X., \& Bartol, K. M. (2010). Linking empowering leadership and employee creativity: The influence of psychological empowerment, intrinsic motivation, and creative process engagement. Academy of management journal, 53(1), 107-128.

Zhang, X., \& Zhou, J. (2014). Empowering leadership, uncertainty avoidance, trust, and employee creativity: Interaction effects and a mediating mechanism. Organizational Behavior and Human Decision Processes, 124, 150-164. 